\title{
Investigations into the cytotoxicity of titania ceramics surfaces
}

\section{Journal Article}

Author(s):

Blum, J.; Eckert, K.-L.; Schroeder, A.; Petitmermet, M.; Ha, S.-W.; Wintermantel, E.

Publication date:

1996

Permanent link:

https://doi.org/10.3929/ethz-b-000422550

Rights / license:

In Copyright - Non-Commercial Use Permitted

Originally published in:

Biomedizinische Technik 41(s1), https://doi.org/10.1515/bmte.1996.41.s1.432 


\title{
Investigations into the cytotoxicity of titania ceramics surfaces
}

\author{
Blum J., Eckert K.-L., Schroeder A., Petitmermet M., Ha S.-W., Wintermantel E.
}

Chair of Biocompatible Materials Science and Engineering, Department of Materials, ETH Zürich, CH-8952 Schlieren, Switzerland

\section{INTRODUCTION:}

Titanium dioxide ceramics are potentially useful as porous cell carrier materials whose properties, such as good permeability, serve to enhance cell vitality. In porous materials, the exchange area is very high, which necessitates high chemical resistance in biological media. This condition can be met by the use of titanium dioxide materials. Furthermore, it was demonstrated that the biocompatibility of titanium and its alloys is associated with the formation of a chemically stable oxide film on the surface $[1,2]$.

Titanium dioxide is commercially available as finegrained powders with crystallite sizes below $1 \mu \mathrm{m}$. As this does not favour the development of porous ceramics, a process was established to increase the grain sizes to between 5 and $15 \mu \mathrm{m}$ [3]. The effect of tantalum and tungsten oxide on grain growth was investigated. Earlier studies revealed that tantalum oxide additions support the formation of porous titanium dioxide ceramics [4]. Tungsten oxide was chosen as an alternative dopant as it acts as a sintering aid.

The cytocompatibility of these materials was assessed by culturing cells on flat samples. As most ceramic studies have concentrated on bone cells, the osteogenic cell line MC3T3-E1 was used. This paper describes the effect of different titanium dioxide materials on cell growth and distribution.

\section{MATERIALS AND METHODS:}

\section{Ceramics:}

Commercial titanium dioxide powder (1171, Kronos) was suspended in water ( $50 \mathrm{wt} \%$ ). $6.52 \%$ tantalum oxide or $2.86 \%$ tungsten oxide $(1 \mathrm{Mol} \%)$ respectively, were added, ball milled, spray dried, and heated to $1300^{\circ} \mathrm{C}$ $(3 \mathrm{~K} / \mathrm{min}$ ) for $20 \mathrm{~min}$. Deagglomeration was achieved by dry milling for $1 \mathrm{~h}$. Small Grains $(<3 \mu \mathrm{m})$ and large agglomerates were eliminated by a sedimentation process (Fig. 1).

$10 \mathrm{~g}$ titanium dioxide powder was mixed with $0.6 \mathrm{~g}$ graphite powder (KS 6, Lonza) and $2.8 \mathrm{~g}$ paraffin (MP $64^{\circ} \mathrm{C}$, Fluka) into a thermoplastic mixture. A composition with reduced porosity was made by mixing $10 \mathrm{~g}$ of undoped powder with $4 \mathrm{~g}$ of as-delivered, untreated powder and $1.5 \mathrm{~g}$ paraffin. The mixture was heated to $100^{\circ} \mathrm{C}$ and pressed into round discs of $15 \mathrm{~mm}$ diameter. After a low-temperature firing cycle for polymer burnout at $300^{\circ} \mathrm{C}$ the samples were sintered at $1350^{\circ} \mathrm{C}$ for $20 \mathrm{~min}$. Finishing was done by ultrasonic cleaning for $15 \mathrm{~s}$ and flushed with deionized water. Open porosity was measured by cold water uptake and the material structure was assessed by SEM (Hitachi S $2500 \mathrm{C}$ ).

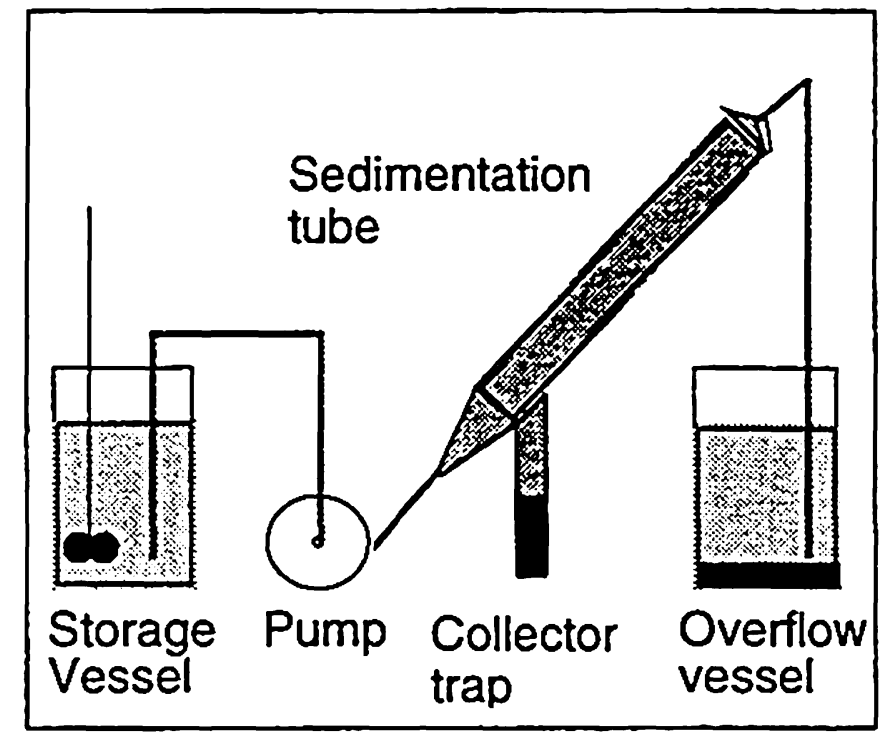

Figure 1: Sedimentation device for separation of grain fractions. The suspension is pumped into the sedimentation tube where the coarse fraction settles in the collector trap. Fine material is drawn into the outlet vessel. The grain size of the fractions can be varied by alteration of the pump rate.

\section{Cytocompatibility Assays:}

Cytocompatibility testing was performed using the osteogenic cell line MC3T3-E1 (Dept. Pathophysiology, Uni. Bern, Switzerland) cultured in $\alpha$-MEM medium containing $5 \%$ fetal calf serum and antibiotics (all from Gibco) at $37^{\circ} \mathrm{C}$ and $5 \% \mathrm{CO}_{2}$. Test ceramic discs were individually placed in wells of 24 well tissue culture plates (Nunc), seeded at 5000 cells/well in $1 \mathrm{ml}$ medium and incubated with medium change every 3 days. Cells in wells without ceramics were used as positive controls. All determinations were carried out in triplicate.

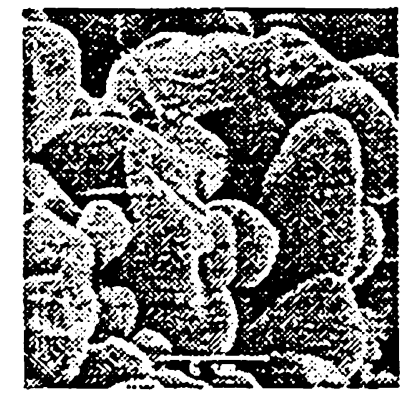

Figure 2: $\mathrm{TiO}_{2}$ undoped, $x 5000$. Large grains with elongated morphology prevai.l

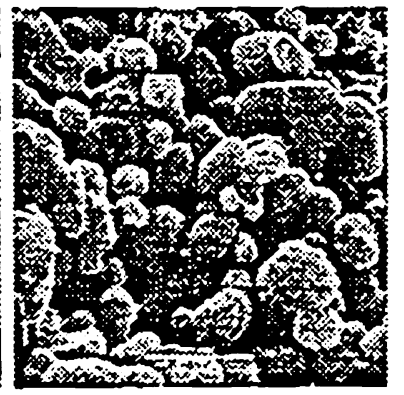

Figure 3: $\mathrm{TiO}_{2}$, $\mathrm{Ta}_{2} \mathrm{O}_{5}$-doped, x5000. Small grain size and open structure are formed.

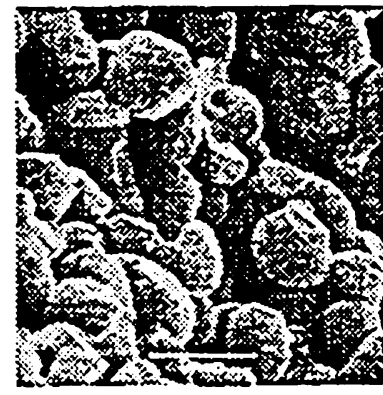

Figure 4: $\mathrm{TiO}_{2}$, $W \mathrm{O}_{3}$,-doped $x 5000$. Grains have rounded morphology.
Proliferation of cells on ceramic samples was evaluated with the MTT test [5]. At intervals, medium from sample wells was replaced with $100 \mu \mathrm{l}(5 \mathrm{mg} / \mathrm{ml}) \mathrm{MTT}$ (Sigma) in phosphate buffered saline (PBS).and incubated for $1.5 \mathrm{~h}$. Reduction of MTT into a colored tetraformazan 
